\title{
REPUBLIC OF TAJIKISTAN: CONFLICTS IN TRANSITION TO NATIONAL DEVELOPMENT
}

\section{Zikirova Nafosat Qarshiboevna}

Independent researcher at the "National ideology «Academic Department at the Faculty of social Sciences of the National University of Uzbekistan

Abstract: This article reflects the research on the development concept, programme, strategy that covers the content of "the national development model", and its social, political, economic and cultural-moral life and which was adopted in accordance with social media features, character and mentality. In particular, it contains analyses of the Concept "oriented for mixed economy", the 1995-2000 Programme of "reorganization of the economy of the Republic of Tajikistan" based on the above Concept, also the ten year "National Development Strategy", adopted in 2007 and the main emphasis is given to economy, improvement of the public management system and development of human potential.

Keywords: national development model, economic, political, and culturalmoral life, oriented for mixed economy, a deep crisis, traditionalism and communitarianism, religious organizations, political activities, political parties.

The national development model is a much broader notion than transition to market economy relations; it includes the economic development model. Therefore, "national development route" means the development concept, programme, strategy that covers contemporary social, Social science and humanities

Generalization of scientific results 
political, economic, and cultural-moral life of a state, adopted in accordance with social medium features, nature, and mentality. Sometimes it is also called "a theoretical model" [1; C.3.]. Generally, an economic model includes establishment of industrial production, agriculture, foreign economic relations, trade, labour processes, transport communications, while a political model is intended for streamlining management of state and society, establishment of social relations, addressing internal and foreign policy issues, also, problems of the economic field. Broadness of the political model is explained by universality of social management functions of state, the vast reach, affiliation with the entire social existence and life of the community. Radical changes in social life require the state to be a strong institution, thus, the social life related models are developed and implemented with state assistance and support. Therefore, national development models cover economic, political, and cultural-moral life related issues.

Social development may not be based on assumed, guessing, unreal models that cannot be covered by certain plans. The Bolsheviks idea of building communism all over the world was such an unreal idea and the political and economic model they had established ended with a deep crisis. This bitter lesson of history imposes certain requirements (they should correspond to life and needs of people, supported by rational plans, improving activeness of people, urging to creativity and innovations, support of modernization) to national development models. Of course, it is impossible to make absolute forecasts for social development and determine it in accordance with plans. As K. Copper wrote using E. Guessy's thoughts: "History of humanity is nothing more than a history of victories and losses in creation of norms that support social life in political and social fields" [2; C.625.]. Yes, the history of humanity also includes "victories and losses" in the history of certain nations and societies. However, although hypothetically, the intentions of taking the social development to a target level, to a state and degree should cause optimism within the community, urge people to creativity and labour. Depression among people leads to final decay of the state. Therefore, the society and state need development models that take to a positive purpose, and that initiate optimistic mood [3; C.12.].

Though the Republic of Tajikistan that gained its independence in 1991, declared itself a democratic, rule-of-law and unitary state ${ }^{1}$, its social-political system could not get rid of the calls of the old regime for "perestroika" and

\footnotetext{
${ }^{1}$ The Constitution of the republic of Tajikistan. Adopted on 6of November 1994. - Dushanbe, 1998. - p.2. Social science and humanities

Generalization of scientific results
} 
"development of democracy. The First President of the country R. Nabiev, not only because he had been a member of CPSU, but also he had got used to live in the traditions of the existing social-political system. The traditionalism and communitarianism that are specific to the Tajik people, was not absolutely prepared for, nor wanted modernization of the society after gaining independence. In formal sources, it was a tradition to sing praises to the existing regime. They kept repeating that during the Soviet era Tajikistan had turned into an agricultural-industrial republic, and in comparison with 1913, agricultural production had risen by 10 times, raw cotton production from 32000 tons to 1.01 million tons, industrial goods production had gone up by 156 times[4;C. 289.].Yes, Tajikistan achieved a lot during the Soviet era; it was the second in the country in hydro-energy resources; in 1989 the subsidies from the Soviet Union budget for Tajikistan reached 31.3\% [5; C.277.]. Together with the values in formal sources, "people's democracy" also sprung to life in later 1980's. Setting democratic development as the purpose, declaration of this by $\mathrm{CP}$ of Tajikistan set the forces with trends of political and cultural changes to move. This resulted in establishment of the Democratic Party of Tajikistan (DPT), Islamic Renaissance Party (IRP), "Rastokhez" Social-Political Movement, "Ru-ba-Ru" Discussin Club, "La'liBadakhshon", "EhyoiHujand", "NosiriKhisrav", "Bokhtar", "DirafshoiKoviyon", "KurushiKabir" unions. "Their programmes and charters had democratic features and anti-communist orientation" [6; C.78.].Here we observe the influence of the process of establishing democratic movement, parties, and opposition groups in the Russian Federation. On the other hand, influence of such factors like Iranian Islamic groups and support of Islam religion is also noted. Islam religion that is deeply seated in life style and mentality of Tajik people brought IRP to the social-political arena. As a result, this led to open conflicts from 1992 between the ruling communists and IRP - supporter of "people's democracy" and traditions, and of religion.

Fearing from the serious threat to come from activities of the groups supported by IRP and religious masses (this was grounded, of course), on the 8 of December 1990, the government adopted the Law "About freedom of conscious and religious organizations". According to Article 5 of this law, it is prohibited for religious organizations to run political activities, participate in activities of political parties and rendering financial aid to political parties. Along with this, an amendment was introduced to the Constitution of Tajikistan to note that the country is a secular state [7; C.392. and 8; C.297.]. In reality, this meant declaring that religious organizations with political trends Social science and humanities

Generalization of scientific results 
were illegal. The public opinion poll in 1996 arranged by IFES and "Sharq" Centre determined that $90 \%$ of population considered themselves as Muslims [9; C.24.]. Thus, Islam factor was deeply seated in people's mass conscious, and IRP and its leaders could not forget this. Therefore, "Islam became a broad coverage factor of political processes [10; C.136.].But the orthodox, atheistic oriented ruling class neither wanted to know this, nor take it into account. The fact that the ruling group did not want democratic changes, the nomenclature urged IRP unite with political parties and forces that were for democratic reforms. As a result, IRP became a large social-democratic force and raised the status of the opposition. It was natural that the United Opposition of Tajikistan (UOT) would take advantage of the situation. So, IRP and political groups around it demanded changing the phrases of "secular state" in the Law "About freedom of conscious and religious organization" and the Constitution of the country. This was a call to build an Islamic state in Tajikistan. Indeed, at a conference in February 1999, IRP leader Hikmatzoda announced that their party's intention was to build an Islamic state, where only men would work [10; C.140.]. According to S. Olimov, who studied this issue, in Qarotegin, where the civil war was initiated under pressure of UOT, there were over 2000 women with University education and over 3000 women with secondary-special education? After the civil war, this number dropped to 18 and 759[10; C.140.].According to the information spread in Internet, to-date, IRP has been declared an extremist, terrorist organization. ${ }^{2}$

In 1997, civil war was finally stopped, and peace, truce and calmness was achieved in Tajikistan. Over 100000 people were killed during this civil war, around 2 million people had to leave their homes, economy and state management bodies' activities were out of order. Diasporas of "Tajikrefugees" appeared in various areas of Central Asian region. All of this prevented Tajikistan from developing and implementing a political model. This resulted in establishment of "extremely diverse types of government. The districts near the Pamirs had almost theocratic management, in some Northern districts, they had secular autocratic system, in Khatlon and Mountainous Badakhsan oblasts they had Islam and Government harmonisation. And Ismaelite ideas are seeing reconnaissance in national conscious of Badakhshan people" [10; C.140.].

${ }^{2} 2017 / 09 / 20$ Mukhiddin Kabiri - The number of disappointed people in Tajikistan is growing by the day. Published on 20 of September 2017.

Social science and humanities

Generalization of scientific results 
The Constitution of the Republic of Tajikistan states that the country is a unitary democratic social-rule-of-law state. In reality, this means that the country had chosen a secular type state model. However, implementation of the statement is subject to resolution of the above problems. These were added by economic problems and are making the young state live a "hard national rehabilitation" process. Therefore, some analysts call "the Tajik civil conflict as the largest and most blood-drenched tragedy in the territory of former Soviet Union" [11; C.116.].

Scholars call the model of transition to market economy "a socially oriented market economy" $[1 ; 12 ; 13 ; 14$.].This term is also mentioned in the works of the country's leader E. Rahmon and those researchers, who give theoretical grounds of the president's activities. In conclusion, certain understanding of this model can be drawn by studying the sources and works about social life and transformation changes.

According to World Bank and information about economy, during the initial five years of independence, the economy of the Republic of Tajikistan reached the level of year 1970. The state budget was reduced to $50 \%$. Population poverty rate achieved $70 \%$. Gross Domestic Product dropped by $58 \%$, production of agricultural goods by $40 \%$, production of industrial commodities dropped by $57 \%$. By 1996 , cotton production and processing dropped by 2.5 times [15; C.37.].

In 1994, the government of the country adopted the Concept, oriented for a "mixed economy" for stabilization of macro-economy, and in 1995 based on the Concept - "The Programme of rehabilitation of the economy of the Republic of Tajikistan for 1995-2000 was adopted." This model stipulates mining industry, base metals metallurgy, hydro-energy as priority fields and sets these industries as the objectives for the government. The measures for ensuring peace urged to develop economy and helped achieve some success.

For instance, while in 1995 the domestic material production in macroeconomy made 308 billion somonies (1.034 million US dollars), by 1998 it was 1025 billion somonies (1.242 million US dollars)[15; C.39.].

It was obvious that the government had to bother about persistent high level of population poverty. In addition, the proportion of the rich and poor people was getting wider; most of population was struggling to find jobs, earning necessary amounts of funds, participation in market economy in equality. In 1998, the government developed a poverty elimination strategy. However, there was no sufficient economic basis and opportunities to implement this plan. In 2007, the government adopted "Strategy for reducing Social science and humanities

Generalization of scientific results 
poverty - 2", and in 2010 - "Strategy for reducing poverty-3." Unfortunately, there is no clear information as to what results have these plans achieved, but they must have led to something. For, according to information for 2015, the poverty level of population in Tajikistan dropped to 31\% [16].

The following objectives are set as priorities in the economic model of the Republic of Tajikistan:

1) ensuring economic independence through reorganisation of industry fields;

2) solution of the issues related with deep aluminium processing to produce final products from local resources;

3) processing of cotton thread in the country;

4) Creation of a unified national economic complex of the Republic for Tajikistan [14; C.299.].

Ensuring economic independence is the main requirement for transition to market relations. This requirement is reflected in market economy transition models of the Central Asian countries. Economic independence is subject to denationalization of property, formation of private property and support of entrepreneurship and small business.

"On one hand, private property reflects permanent and temporary, partial or total mutual influence between a certain person or a group of people, on the other hand, between any substance of the material world and the object, i.e., possessing of the object by the subject" [17;81-p.]. Indeed, "possessing of an object by a subject" is the basics of ensuring independence of economy. Central Asian countries have been trying to prevent private property owners from going bankrupt, and supporting small business and private businessmen as much as possible. The national features of transition to market economy require this.

By 1900's, private sector started becoming the most important part of economy in Central Asian countries. For instance, in 1900's 75\% of ablebodied part of the population of Kazakhstan was busy in private sector, while in Kyrgyzstan $77 \%$, Uzbekistan $72 \%$ of population were hired by private sector. Among CIS countries, this value was 59\% in the Republic of Tajikistan and $54.9 \%$ in Turkmenistan [18; C.181.]. This shows that the public sector is still prevalent. According to some information, up to $12 \%$ of state property was privatized during 1998-2000[20; C.241.].

Small business and private entrepreneurship is the most effective method of creating jobs for population. Experience of developed countries shows that almost $60-70 \%$ of population is hired in private sector. They are Social science and humanities

Generalization of scientific results 
middle class of the society and actively participate in solution of socialeconomic issues. This very value urged the Central Asian countries to address development of small business and private entrepreneurship as the state policy.

By 2007 , only $48 \%$ of able-bodied part of the population of the Republic of Tajikistan was busy in private sector. This shows that almost $52 \%$ of gross domestic product is held by the state. Although in 2009 the authorities commissioned "The 200 days reforms" Programme and "one stop shop service," development of small business and private entrepreneurs is still very slow. One of the major causes of this is bureaucracy, endless normativelegislative requirements [14; C.304.].

The government of Tajikistan tries to support farmers. For instance, in 2008 , the government of the country decided to extent payback deadline of the 500 million dollars debt to farmers, and in 2009, the government waived from 424 million dollars debt. They developed special measures to establish family farmer's entities, allocating them with land and lending funds. Only in 2012, 65000 families obtained licenses for farming, and this resulted in $75 \%$ of able-bodied population to be busy in agriculture. This indeed, was an important help to country's economy [19; C.40 - 41.].

In 2007, the government of the country developed and adopted "The National Development Strategy." However, due to the global financial crisis it was impossible to implement and finalize the targeted objectives. For instance, foreign trade turnover that brings hard currency to the country dropped by $23.4 \%$, capital expenses share - by $41.8 \%$ and industrial production by $12.2 \%$. Proceeds from sales of aluminum dropped by $46 \%$, which resulted in 100 million dollars loss. Cotton production was reduced by $28 \%$; in 2009 economic growth stopped at 3.9\% [14; C.306.].

World financial crisis made the country cut internal expenditure. The income parts of 2009 budget was reduced by $9.8 \%$ and expenditure part - by $9.6 \%$, which made cutting costs for education, science, social supplies, pensions and stipends[14; C.310.]. Although the plans of the government for elimination of 2009-2010 financial crisis damages did not cause any noticeable effect in economic development, it prevented from going back to the soviet era status. However hard it was, the government managed to ensure the country's economy to work and serve the needs of the population. By the middle of 2010, the economy resumed growth. Aluminum and cotton demand rose at world markets and their prices recovered and the country gained its hard currency proceeds back. 
Visits of the President of Tajikistan E. Rahmon in 2012-2015 to neighboring countries and bilateral contracts signed facilitated improvement and development of economic relations. During these years, the country signed over 70 contracts in economic, cultural-humanitarian fields. This resulted in economic growth of $6.7 \%$ in 2015[16]. Though the press does not pay sufficient attention to execution of these contracts, they showed that the economic development model of Tajikistan has transitive nature [1; C.13-14.]. In other words, this country reflects the transition period conflicts and has an objective of implementing, though slowly, the world experience into their national land.

So, how are they implementing the objective of establishing "the unified national economic complex in the Republic of Tajikistan" in the economic model? What is it? What is the national aspect of it? What are the major subjects of it and what is their standing, share in the economic model? What are the differences of this complex from those in the Soviet era (Agricultural industry complex, metallurgical complex, and food and trade complexes)? These questions have not been given any answers, nor have they been discussed yet. There is a sense that this complex assumes the infrastructure that is available in the territory of the Republic of Tajikistan. This prevents from determining the economic model, abstracts the objectives of the model.

There is a number of problems of political-economic and organization nature in the objective of ensuring the economic independence. The issues of developing small business and private entrepreneurship are still in the hands of traditional thinking bureaucrats, who never forget their personal interests. There is a burning need for professionals with modern thinking, who are able to perform innovative search.

The experience of Tajikistan showed that it is not easy to build a true democratic social-rule-of-law state, and that unexpected conflicts may occur, destructive forces may rise and such may even turn the country's development to a different way. However, the political power of Tajikistan, its people are prepared for innovative search, modernization of economy in the best interests of the nation; it only needs their wishes, dreams, and demands to be heard and supported. It is the political government's function to unite the society, people around the national democratic development objectives. 


\section{References:}

1. Akhmedova D.A., Economic model of the Republic of Tajikistan. Extended abstract of dissertation of cand.of.econ.sciences. - Dushanbe, 2010 p. 13.

2. Popper C. Assumptions and denials: Growth of scientific conscious Moscow: AST-ERMAK, 2004, - p. 638.

3. Abilov U.M., OPtmism (social-philosophic analysis). - Tashkent, Fan, 1994. - p. 204.

4. Indestructible union. 1922 - 1982. Reference book. - Moscow: Pol. Literature publisher, 1982. - p. 462.

5. Post-Soviet Central Asia. Losses and gains. - Moscow: Inter gr.., 1998 - p. 428.

6. Imomov A. Formation of civil society in Tajikistan: problems and comments.// Central Asia and Caucasus, 2002, №3(21). - p.78-85.

7. Bulletin of the Supreme Council of Tajik SSR, 1990, №23- p.380-397.

8. Bulletin of the Supreme Council of Tajik SSR, 1990, №24. - p.289 298.

9. Wagner S. Public opinion in Tajikistan. 1996 г. - Washington, Un Press, 1997. - p. 108.

10. OlimovaS..Political Islam and conflict in Tajikistan//Central Asia and Caucasus. 1999, №4(5). - p.133 - 141.

11. Maslov V. State structure in ensuring political stability of Cenrtral Asian countries//Central Asia and Caucasus. 2000, №5(11). - p.111-120.

12. AbdugafarovA..Economic isolation and independence of companies in conditions of transition to market economy. - Khujand, R. Jalil publishing house, 2006. - p. 238.

13. Zhukov S.V. Reznikova O.B. Central Asia in social-economic structures of modern world. - Moscow: Finansist gr., 2001. - p. 288.

14. Social-economic developmentof Post-Soviet countries: results of past twenty years. - Moscow: RAS Economy, 2012. - p.400.

15. Post-Soviet countries and financial crisis of Russia. - Moscow: AOZT “Enikon", 2000. - p.304.

16. Central Asian countries facing systemic crisis// Asia Plus, 2016, 15 of April.

17. Usmonov S.N. Dadaboev Y.T. Basics of market economy.Tashkent: Fan, 1999. - p.288. 
18. Topilin A. Demographic potential of Caucasus, Central Asian countries and general labour market// Central Asia and Caucasus, 2000, №3(9). - p.177 - 187.

19. World Bank report. January 2011. - p.328.

20. Danilov A.A.Transitional society. Systemic transformation problems. - Minsk: LLC “Harvest”, 1998. - p.432. 